\title{
Development of a gene cloning system in a fast-growing and moderately thermophilic Streptomyces species and heterologous expression of Streptomyces antibiotic biosynthetic gene clusters
}

\author{
Weihua Chen and Zhongjun Qin ${ }^{*}$
}

\begin{abstract}
Background: Streptomyces species are a major source of antibiotics. They usually grow slowly at their optimal temperature and fermentation of industrial strains in a large scale often takes a long time, consuming more energy and materials than some other bacterial industrial strains (e.g., E. coli and Bacillus). Most thermophilic Streptomyces species grow fast, but no gene cloning systems have been developed in such strains.

Results: We report here the isolation of 41 fast-growing (about twice the rate of $\mathrm{S}$. coelicolor), moderately thermophilic (growing at both $30^{\circ} \mathrm{C}$ and $50^{\circ} \mathrm{C}$ ) Streptomyces strains, detection of one linear and three circular plasmids in them, and sequencing of a 6996-bp plasmid, pTSC1, from one of them. pTSC1-derived pCWH1 could replicate in both thermophilic and mesophilic Streptomyces strains. On the other hand, several Streptomyces replicons function in thermophilic Streptomyces species. By examining ten well-sporulating strains, we found two promising cloning hosts, $2 \mathrm{C}$ and 4F. A gene cloning system was established by using the two strains. The actinorhodin and anthramycin biosynthetic gene clusters from mesophilic S. coelicolor A3(2) and thermophilic $S$. refuineus were heterologously expressed in one of the hosts.

Conclusions: We have developed a gene cloning and expression system in a fast-growing and moderately thermophilic Streptomyces species. Although just a few plasmids and one antibiotic biosynthetic gene cluster from mesophilic Streptomyces were successfully expressed in thermophilic Streptomyces species, we expect that by utilizing thermophilic Streptomyces-specific promoters, more genes and especially antibiotic genes clusters of mesophilic Streptomyces should be heterologously expressed.
\end{abstract}

\section{Background}

Streptomyces species are high $\mathrm{G}+\mathrm{C}$, Gram-positive bacteria that are a major source of natural products, producing about half of all known microbial antibiotics [1]. Members of this genus also have a complex life cycle, in which uni-genomic spores geminate to produce a multigenomic substrate mycelium of branching hyphae which gives rise to aerial hyphae and ultimately to spores [2].

\footnotetext{
* Correspondence: qin@sibs.ac.cn
Key Laboratory of Synthetic Biology, Shanghai Institute of Plant Physiology

* Correspondence: qin@sibs.ac.cn
Key Laboratory of Synthetic Biology, Shanghai Institute of Plant Physiology and Ecology, Shanghai Institutes for Biological Sciences, the Chinese Academy of Sciences, 300 Fenglin Road, Shanghai, 20032, People's Republic of China
}

(c) 2011 Chen and Qin; licensee BioMed Central Ltd. This is an Open Access article distributed under the terms of the Creative Commons Attribution License (http://creativecommons.org/licenses/by/2.0), which permits unrestricted use, distribution, and reproduction in any medium, provided the original work is properly cited.

Streptomyces coelicolor A3(2) is the genetically most studied Streptomyces species from the in vivo through in vitro to in silico phases and is an excellent model for studying antibiotic production and differentiation [3,4]. Mainly because of a strong restriction barrier to introduction of foreign double-stranded DNA by transformation from Escherichia coli into A3(2), the closely related S. lividans, with no such barrier and cured of indigenous plasmids (SLP2 and SLP3: [5]), has been used as a standard host for gene cloning and expression for several decades [6]. However, compared with E. coli and Bacillus subtilis, S. coelicolor and S. lividans (also other species from the genus Streptomyces) grow slowly at their 
optimal temperature (e.g., S. coelicolor M145 - a plasmid-free derivative of A3(2) - grows exponentially with a doubling time of about $2.2 \mathrm{~h}$ on SMM medium at $28^{\circ}$ C, see ref [6]). It takes about 2-3 weeks for Streptomyces strains to produce and accumulate antibiotics at a good yield on an industrial scale.

Fast-growing, thermophilic Streptomyces strains have been studied for a long time. Some earlier described thermophilic Streptomyces species (e.g., S. thermophilis and $S$. thermofuscus: $[7,8]$ ) were not classified as thermophilic streptomycetes $[9,10]$. Numerical classification of thermophilic streptomycetes showed three major, five minor and two single-member clusters [10]. Analysis of the 16S rRNA genes and morphological and chemical properties indicate their classification within the genus Streptomyces [11,12]. Most thermophilic Streptomyces species have growth temperature ranges from 28 to $55^{\circ} \mathrm{C}$ and so are only moderately thermophilic $[11,12]$. However, some thermophilic Streptomyces species can grow up to $68^{\circ} \mathrm{C}$ [13]; the optimum growth temperature of $S$. thermoautotrophicus is $65^{\circ} \mathrm{C}$ and no growth is observed below $40^{\circ} \mathrm{C}$, so it is a truly thermophilic strain [14]. Growth of thermophilic Streptomyces strains is rapid at high temperature [15]; for example, S. thermoviolaceus has a doubling time of $1 \mathrm{~h}$ at $50^{\circ} \mathrm{C}$ [16]. Thermophilic Streptomyces species produce thermostable enzymes and antibiotics [15], such as xylanase [17], alpha-amylase [18], granaticin [16] and anthramycin [19]. Since thermophilic Streptomyces strains lack a genetic manipulation system, mesophilic strains (e.g. $S$. lividans) have been employed for expression of some genes or antibiotic biosynthetic gene clusters from thermophilic Streptomyces species [20-22].

We report here the development of a gene cloning system in a fast-growing (about twice the rate of S. coelicolor) and moderately thermophilic (growing at both $30^{\circ} \mathrm{C}$ and $50^{\circ} \mathrm{C}$ ) Streptomyces strain, and successful heterologous expression of antibiotic biosynthetic gene clusters from both thermophilic and mesophilic Streptomyces species.

\section{Results and Discussion}

Isolation and identification of thermophilic Streptomyces strains from various soil samples

To isolate thermophilic Streptomyces strains, various soil samples from China were collected (see Methods). As summarized in Table 1, 22, 11 and eight strains were isolated from samples of garden soil, weed compost and swine manure, respectively. Thermophilic Streptomyces species have been isolated from composts, soil and sewage [23], as well as lakes and hot-springs [13]. Our results reinforce the idea of a widespread occurrence of these organisms.

To determine if these strains should be classified in the genus Streptomyces, 16S rRNA genes were amplified, cloned and sequenced. The sequences displayed high homology (97-99\%) to those of known mesophilic Streptomyces and/or thermophilic Streptomyces species. A phylogenetic tree was drawn by using a neighbor-joining method [24]. The chosen 11 newly isolated strains have distinct phenotypes when cultured on R2YE and MS media, and the reference strains utilized for comparison are well-classified Streptomyces species. As shown in Figure 1, all 11 newly isolated strains $(4 \mathrm{~F}, \mathrm{~T} 6 \mathrm{C}-1, \mathrm{~T} 1 \mathrm{~A}$, T6E-2. X4-3, T6-1-4, X3-3, 2C, T5A-1, T6A-2 and T6A3) resembled known thermophilic Streptomyces species (e.g., S. thermocarboxydus, S. thermoviolaceus and S. glaucescens). Moderately thermophilic Streptomyces species form at least two distinct clades $[12,23,25]$, containing strains related to $S$. megasporus and S. thermodiastaticus, respectively. The phylogenetic tree of the 11 newly isolated strains reveals more clades (e.g., T5A-1 and T6E-2; see Figure 1). These results indicate that moderately thermophilic Streptomyces species are diverse in natural habitats.

Like typical Streptomyces species, these newly isolated strains produced spores on R2YE and MS media. Scanning electron microscopy showed that strains $4 \mathrm{~F}$ and $2 \mathrm{C}$ formed long chains of smooth-surfaced spores after growth on MS medium at $42^{\circ} \mathrm{C}$ for $2 \mathrm{~d}$ (data not shown). Thus strains $4 \mathrm{~F}$ and $2 \mathrm{C}$ were classified in the genus Streptomyces.

\section{Characterization of the fast-growing and moderately- thermophilic Streptomyces strains $4 \mathrm{~F}$ and $2 \mathrm{C}$}

As shown in Figure 2, strains $4 \mathrm{~F}$ and $2 \mathrm{C}$ were able to grow from 30 to $50^{\circ} \mathrm{C}$, while two mesophilic Streptomyces strains (S. coelicolor M145 and S. venezuelae ISP5230) grew at $30^{\circ} \mathrm{C}$ and $37^{\circ} \mathrm{C}$. $4 \mathrm{~F}$ and $2 \mathrm{C}$ grew well at $45^{\circ} \mathrm{C}$ and $50^{\circ} \mathrm{C}$ but poorly at $55^{\circ} \mathrm{C}$, while M145 and ISP5230 could not grow at $45^{\circ} \mathrm{C}$ and $50^{\circ} \mathrm{C}$ (data not shown). Thus, $4 \mathrm{~F}$ and $2 \mathrm{C}$ were concluded to be moderately thermophilic Streptomyces strains.

Strains $4 \mathrm{~F}$ and $2 \mathrm{C}$ grew on MS medium at $37^{\circ} \mathrm{C}$ and $45^{\circ} \mathrm{C}$ faster than the mesophilic Streptomyces strains at $30^{\circ} \mathrm{C}$ and $37^{\circ} \mathrm{C}$ (Figure 2). To measure the growth rates of $4 \mathrm{~F}$ and M145, equal numbers of spores were inoculated into TSB liquid medium, and three mycelial samples were harvested at various points during the time course. Each sample was weighed, and the three values were averaged for a particular time point. As shown in Figure 3, 4F rapidly accumulated biomass to a maximum at $45^{\circ} \mathrm{C}$ or $37^{\circ} \mathrm{C}$ within $16 \mathrm{~h}$, then the growth curve fluctuated, and the final biomass of strain 4F is higher for M145 (especially at $45^{\circ} \mathrm{C}$ ). The oscillations shown at 37 and $45^{\circ} \mathrm{C}$ resembling the "death/growth process" of S. coelicolor A3 (2) in liquid medium with a diluted inoculum [26]. The doubling times of growth for $4 \mathrm{~F}$ at $30,37,45$ and $50^{\circ} \mathrm{C}$ and M145 at $30^{\circ} \mathrm{C}$ and $37^{\circ} \mathrm{C}$ in each logarithmic phase 
Table 1 Strains used in this study

\begin{tabular}{|c|c|c|}
\hline Strains & Genotype or description & $\begin{array}{l}\text { Source or } \\
\text { reference }\end{array}$ \\
\hline \multicolumn{3}{|l|}{ Streptomyces } \\
\hline S. coelicolor M145 & $\mathrm{SCP} 1^{-} \mathrm{SCP} 2^{-}$ & {$[6]$} \\
\hline S. lividans 1326 & SLP2 SLP3 & {$[6]$} \\
\hline S. lividans ZX7 & pro-2 str-6 rec-46 dnd SLP2- SLP3- & {$[37]$} \\
\hline S. venezuelae ISP5230 & A jadomycin B producer & {$[49]$} \\
\hline \multicolumn{3}{|l|}{ Thermophilic Streptomyces } \\
\hline $\begin{array}{l}22 \text { strains (4F, 2C, T1-1, T1-2, T5A-1, T6-5, T6-1-4, T1A, T6A-2, T6A-3, T6B-1, T6B- } \\
\text { 2, T6B-5, T6B-6, T6B-8, T6C-1, T6C-5, T6D-1, T6D-2, T6E-1, T6E-2, T6F-2) }\end{array}$ & $\begin{array}{l}\text { Isolated from garden soil at the Shanghai } \\
\text { Institute of Plant Physiology and Ecology }\end{array}$ & This work \\
\hline 11 strains (G101, G103, G303, G102, G507, G302, 403, 202G, G304, 301, 005) & Isolated from weed manure in Hunan province & This work \\
\hline 8 strains (A1, Z2-1, X1-3, X1-6, X2-1, X3-3, X4-3, X5-5) & $\begin{array}{l}\text { Isolated from swine manure in Hunan, Hubei } \\
\text { and Fujian province }\end{array}$ & This work \\
\hline \multicolumn{3}{|l|}{ Escherichia coli } \\
\hline $\mathrm{DH} 5 \alpha$ & $\begin{array}{l}\text { F- deoR recAl endA1 hsdR17(rk- mk+) phoA } \\
\text { supE44 } \lambda \text { - thi-1 gyrA96 relA1 }\end{array}$ & $\begin{array}{l}\text { Life } \\
\text { Technologies, } \\
\text { Inc }\end{array}$ \\
\hline ET12567 (pUZ8002) & dam dcm hsdM cm kan & {$[6]$} \\
\hline
\end{tabular}

(14-20, 6-12, 8-14 and 12-18 h for 4F at 30, 37, 45 and $50^{\circ} \mathrm{C}$, and $16-22$ for $\mathrm{M} 145$ at 30 and $37^{\circ} \mathrm{C}$ ) were $2.3,1.4$, $1.12 .3,2.2$ and $2.4 \mathrm{~h}$, respectively. Thus strain $4 \mathrm{~F}$ grew at $45^{\circ} \mathrm{C}$ twice and at $37^{\circ} \mathrm{C} 1.6$ times as fast as M145 at $30^{\circ} \mathrm{C}$ in TSB medium.

\section{Identification of one linear and three circular plasmids among 41 strains, and sequencing of pTSC1}

We detected three circular plasmids, $7-\mathrm{kb}$ pTSC1, from X4-3, 7.5-kb pTSC2 from X3-3, and 40-kb pTSC3 as well as 16-kb linear pTSL1 from T6-1-4. The complete nucleotide sequence of the circular pTSC1 consisted of 6996 bp (GenBank accession number GU271942), with $72 \% \mathrm{G}+\mathrm{C}$, resembling that of a typical Streptomyces genome (e.g., 72.1\% for S. coelicolor A3(2): [27]). Eight ORFs (open reading frame) were predicted by "FramePlot 3.0 beta" [28]; seven of them resembled Streptomyces or Mycobacterium genes (Additional file 1, Table S1). Notably, three genes resembled the transfer and spread genes (tra and spd) of Streptomyces plasmids pIJ101 [29] and pSNA1 [30].

\section{Development of a gene cloning system in strains $2 \mathrm{C}$ and 4F}

Followed the standard protocols of preparation and transformation of Streptomyces protoplasts with slight modifications (see Methods), pTSC1-derived pCWH1 (see Methods and Table 2) was introduced by transformation into ten well-sporulating thermophilic Streptomyces strains. Thiostrepton-resistant colonies were obtained for strains $2 \mathrm{C}$ and $4 \mathrm{~F}$ at frequencies of $1.3 \times 10^{3}$ and $2 \times 10^{1}$ per $\mu \mathrm{g}$ DNA, but no transformants arose for the other eight strains. Many Streptomyces selection markers (e.g., tsr, apr, spec, hyg, erm and kan) could be used in strains
2C and 4F. No antibacterial activity (e.g., against Bacillus subtilis, Escherichia coli or Staphyloccocus aureus) was detected in the two strains (unpublished data). Thus, we found two promising cloning hosts, $2 \mathrm{C}$ and $4 \mathrm{~F}$.

Since $2 \mathrm{C}$ and $4 \mathrm{~F}$ were classified in the genus Streptomyces, several mesophilic Streptomyces vectors were employed for transformation experiments. As shown in Table 3, pIJ702 (a pIJ101 derivative, [31]), pZR51 (pFRL2, [32]), pZR115 (pFP1, [33]) and pZR10 (pFP11, [33]) were able to transform both $2 \mathrm{C}$ and $4 \mathrm{~F}$. No transformants were obtained for SCP2 [34], SLP1[35], SAP1 [36] and pSHK1 [32] derivatives (pYQ40, pZR205, pHAQ61, and pGP9, respectively). pCWH1 could also transform S. lividans ZX7 [37] at high frequency $\left(10^{4} / \mu \mathrm{g}\right.$ DNA). A Streptomyces integrating plasmid, pSET152 [38], could be introduced by conjugation from E. coli into many thermophilic Streptomyces strains (14 of 22 strains). Thus, pTSC1-derived pCWH1 can replicate in both thermophilic and mesophilic Streptomyces strains. On the other hand, several Streptomyces replicons, including circular plasmids pIJ101, pFP1 and pFP11 and linear plasmid pFRL2, were able to propagate in the thermophilic Streptomyces strains 2C and $4 \mathrm{~F}$, but no transformants were obtained for circular plasmids SCP2 and SLP1 and linear plasmids SAP1 and pSHK1.

Comparing the transformation frequencies of pIJ702 from different hosts in $2 \mathrm{C}$ and $4 \mathrm{~F}$, as shown in Table 3, similar high frequencies of transformation $\left(2.9 \times 10^{6}\right.$ and $1.3 \times 10^{6}$ ) were obtained in $2 \mathrm{C}$ with pIJ702 from both $2 \mathrm{C}$ itself and the largely restriction-free $S$. lividans ZX7. Low frequencies of transformation $\left(8 \times 10^{1}\right.$ and $\left.3 \times 10^{2}\right)$ were obtained in $4 \mathrm{~F}$ with pIJ702 from $2 \mathrm{C}$ and ZX7, although a high frequency $\left(1.2 \times 10^{5}\right)$ was obtained with plasmid DNA from the strain itself. These results indicated that 


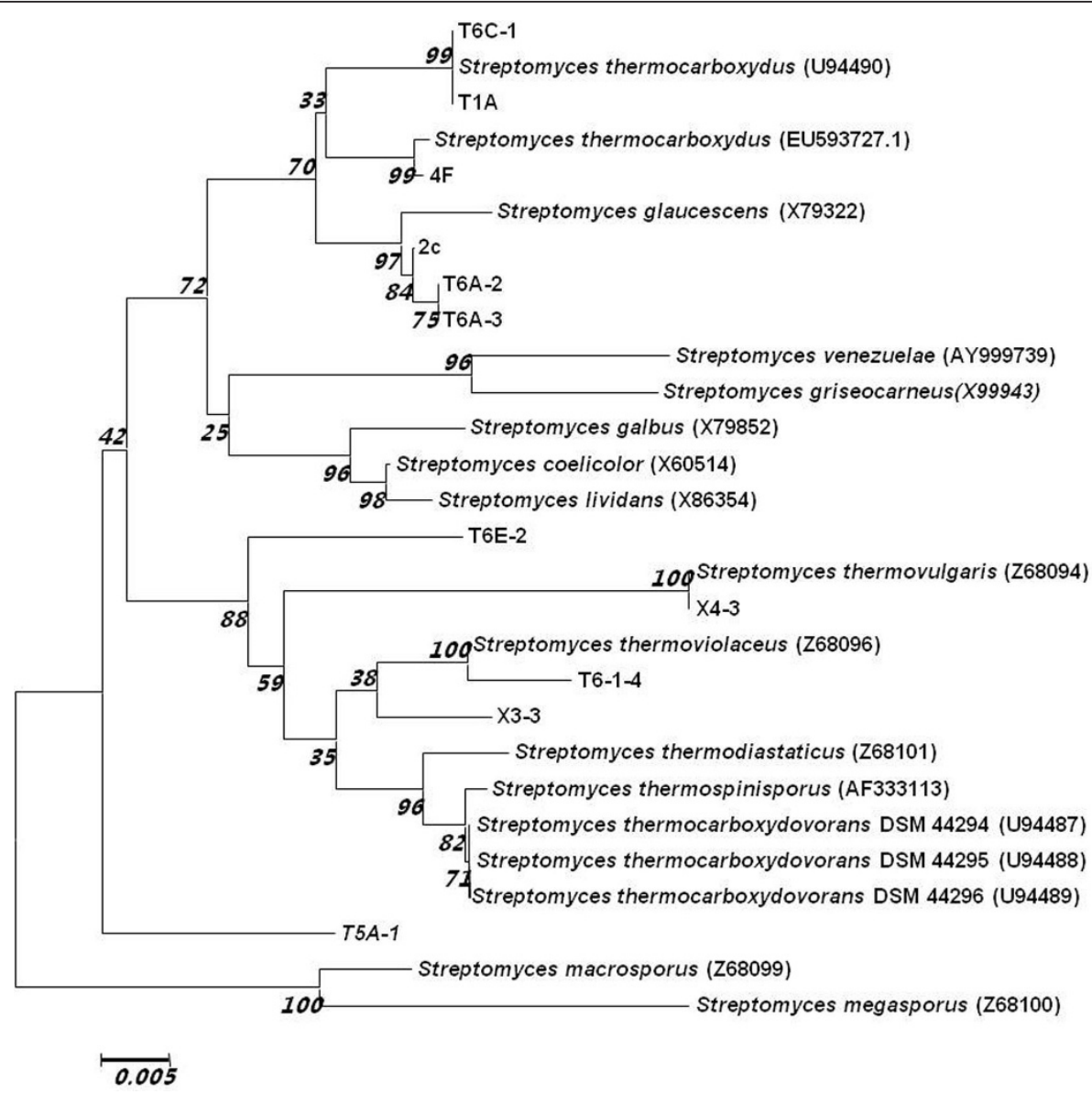

Figure 1 Identification of thermophilic Streptomyces strains. Phylogenetic tree for 11 newly identified strains and some known mesophilic and thermophilic Streptomyces species (Genbank numbers in parentheses). The tree is drawn to scale using the neighbor-joining method, with branch lengths in the same units as those of the evolutionary distances. Numbers next to the branches are the percentage of replicate trees (the bootstrap test is 500 replicates).

strain $2 \mathrm{C}$ showed essentially no restriction barrier to the introduction of foreign double-stranded DNA from other Streptomyces species, whereas strain 4F had a strong restriction barrier. The evaluation of restriction barriers needs much more experimental data to be supported.

\section{Heterologous expression of the actinorhodin biosynthetic} gene cluster of $S$. coelicolor $A 3(2)$ in strain $4 \mathrm{~F}$

Since several mesophilic Streptomyces plasmids functioned in thermophilic Streptomyces, we chose a phage phiC31derived integrating plasmid pSET152 [38] which is inherited stably in other hosts to perform experiment on heterologous expression of antibiotic biosynthetic genes in thermophilic Streptomyces strains. By using PCR with eight primers from the actinorhodin biosynthetic genes (sco5085-5092), we found that no bands for strains 4F and $2 \mathrm{C}$ were detected on agarose gel after electrophoresis of the PCR products, indicating no such genes in the strains. We cloned the complete actinorhodin biosynthetic gene cluster from $S$. coelicolor A3(2) in an integrating plasmid (see Methods), and the resulting plasmid, pCWH74, was introduced by conjugation into eight newly isolated strains, including 4F and $2 \mathrm{C}$. PCR amplification experiments with eight paired primers from SCO5085 to SCO5092 confirmed the presence of the actinorhodin genes in the clones of $4 \mathrm{~F}$ and $2 \mathrm{C}$. Blue pigment was observed for strain $4 \mathrm{~F}$ on both R2YE and MS media at 30 and $37^{\circ} \mathrm{C}$ after growth for $1 \mathrm{~d}$, but no blue pigment was seen at $45^{\circ} \mathrm{C} .2 \mathrm{C}$ with the actinorhodin gene cluster did not produce visible blue pigment on R2YE or MS media. To confirm that the blue pigment was actinorhodin, $4 \mathrm{~F}$ containing pCWH74 was cultured in R2YE liquid medium lacking $\mathrm{KH}_{2} \mathrm{PO}_{4}$ and $\mathrm{CaCl}_{2}$ and the supernatant was treated with $\mathrm{KOH}$ and scanned at $640 \mathrm{~nm}$ [39]. The same pattern of absorption peaks was detected for $4 \mathrm{~F}$ as for S. coelicolor A3(2) (data not shown). Thus the actinorhodin biosynthetic gene cluster from the mesophilic S. coelicolor A3(2) was heterologously expressed in strain 4F at 


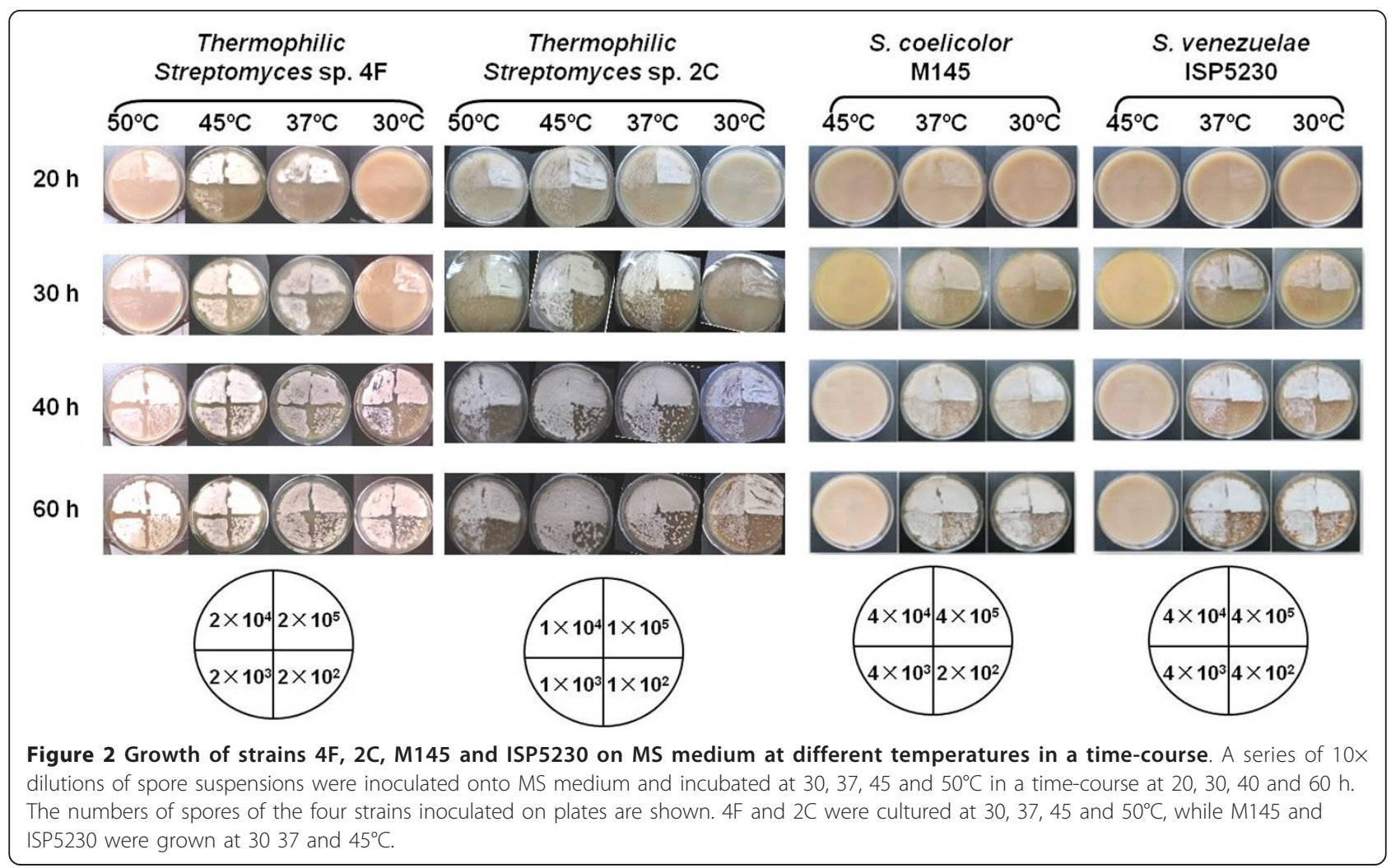

low temperature $\left(30\right.$ and $\left.37^{\circ} \mathrm{C}\right)$, but not at high temperature $\left(45^{\circ} \mathrm{C}\right)$.

To quantitate the productivity of actinorhodin, equal amounts of spores of M145 and 4F containing pCWH74 were inoculated into R2YE liquid medium lacking
$\mathrm{KH}_{2} \mathrm{PO}_{4}$ and $\mathrm{CaCl}_{2}$, and $1 \mathrm{ml}$ culture was harvested in a time-course. As shown in Figure 4, actinorhodin was produced in $4 \mathrm{~F}$ at both 30 and $37^{\circ} \mathrm{C}$, earlier than in M145 at $30^{\circ} \mathrm{C}$. At $100 \mathrm{~h}$, productivity of actinorhodin in $4 \mathrm{~F}$ at $30^{\circ} \mathrm{C}$ was $\sim 2.8$ times higher than in M145 at $30^{\circ} \mathrm{C}$.

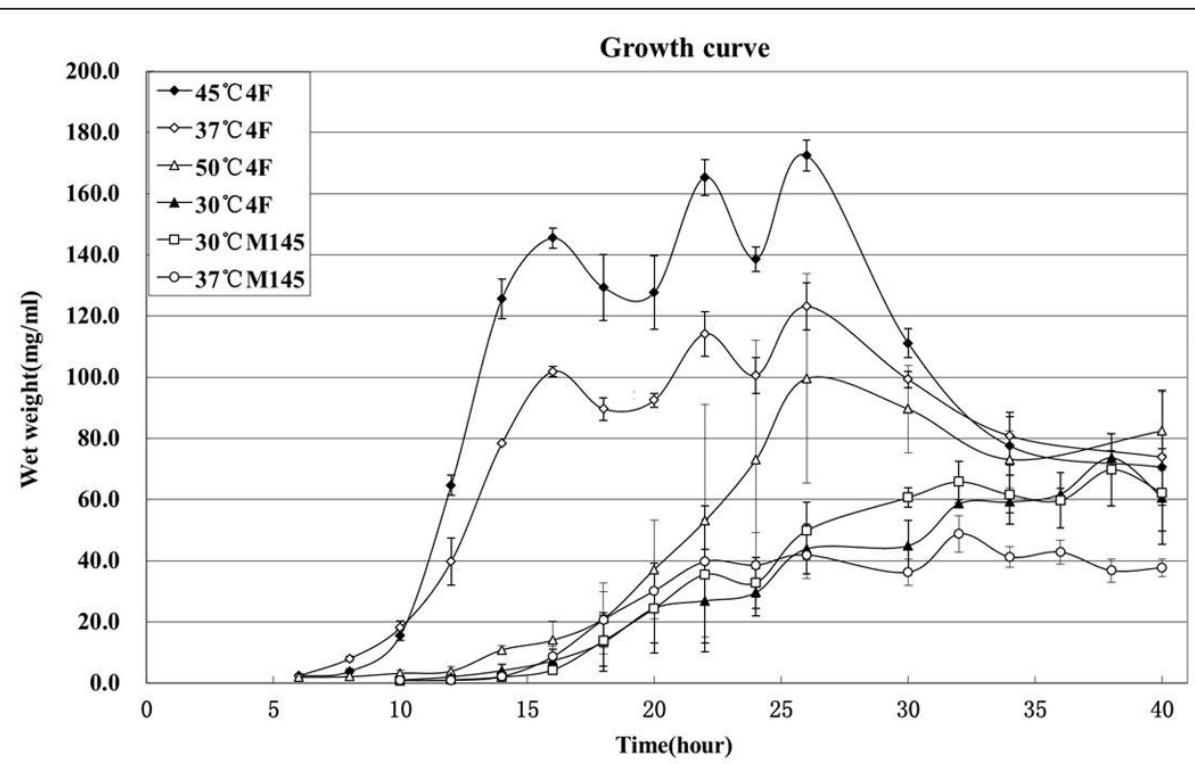

Figure 3 Growth curves of 4F and M145 in liquid culture at four temperatures. The curves are based on the average of three weighings at each time point, and standard deviations are indicated. 
Table 2 Plasmids used in this study

\begin{tabular}{|c|c|c|}
\hline Plasmids & Genotype or description & $\begin{array}{l}\text { Source or } \\
\text { reference }\end{array}$ \\
\hline pTSC1 & A 6996-bp plasmid of strain X4-3 & This work \\
\hline pTSC2 & A $7.5-\mathrm{kb}$ plasmid of strain $\times 3-3$ & This work \\
\hline pTSC3 & A $50-\mathrm{kb}$ plasmid of strain T6-1-4 & This work \\
\hline pTSL1 & A $16-\mathrm{kb}$ linear plasmid of strain T6-1-4 & This work \\
\hline pSP72 & amp colEl-ori & $\begin{array}{l}\text { Life Technologies, } \\
\text { Inc }\end{array}$ \\
\hline $\begin{array}{l}\text { pBluescript } \\
\text { II SK }\end{array}$ & amp colEl-ori lacZ & Stratagene, Inc \\
\hline pQC156 & A 2.6-kb Bcll-fragment of melC/tsr cloned in pSP72 (Bg/ll) & [46] \\
\hline pCWH1 & A 7-kb Kpnl fragment of pTSC1 cloned in pQC156 & This work \\
\hline pCWH100 & A 7-kb Kpnl fragment of pTSC1 cloned in pBluescript II SK & This work \\
\hline plJ702 & melC tsr plJ101 origin & [31] \\
\hline pZR10 & A 8.9-kb Sau3A1-fragment of pFP11 origin cloned in pQC156 & [33] \\
\hline pZR115 & A 4.1-kb Sau3A1-fragment of pFP1 origin cloned in pQC156 & [33] \\
\hline pZR205 & Two fragments (PCR) of SLP1 rep/imp cloned in pQC156 & [33] \\
\hline pZR51 & A 2.2-kb Hindlll fragment of pFRL2 origin cloned into pQC156 & [32] \\
\hline pHAQ61 & A 2.9-kb fragment of SAP1 origin cloned in pQC156 & $\begin{array}{l}\text { Zhang and Qin, } \\
\text { unpublished data }\end{array}$ \\
\hline pYQ40 & A 2-kb fragment of SCP2 origin cloned in pQC156 & $\begin{array}{l}\text { Yang and Qin, } \\
\text { unpublished data }\end{array}$ \\
\hline pGP9 & A 4.1-kb EcoRI/Bglll fragment of pSHK1 origin cloned in pQC156 & [32] \\
\hline pSET152 & Streptomyces phage $\phi C 31$-derived integration vector, apr & [38] \\
\hline pHAQ31 & amp colEl-ori cos melC tsr & {$[47]$} \\
\hline $\begin{array}{l}\text { Cosmid N7- } \\
85\end{array}$ & pHAQ31 (BamHI) containing c. 33 kb sequence (5510413-5543521 bp) from S. coelicolor A3(2) & This work \\
\hline $\mathrm{pCWH74}$ & $\begin{array}{l}\text { A } 2.6-\mathrm{kb} \text { Xbal/Nhel fragment containing the phiC31 integrase gene cloned in a pHAQ31-derived cosmid } \\
\text { containing the actinorhodin biosynthetic gene cluster }\end{array}$ & This work \\
\hline 024CAO-3 & The anthramycin biosynthetic gene cluster cloned into a cosmid CAO2 & [22] \\
\hline
\end{tabular}

Strains M145 and 4F grew better in TSB than in R2YE liquid media (data no shown), but no actinorhodin was detected when cultured in TSB medium at 30 and $37^{\circ} \mathrm{C}$. Growth curves of the two strains in $\mathrm{R} 2$ lacking $\mathrm{KH}_{2} \mathrm{PO}_{4}$ and $\mathrm{CaCl}_{2}$ at $30^{\circ} \mathrm{C}$ showed that their biomass values were similar from 20 to 120 hours (data not shown). Thus, better growth of M145 and 4F in TSB medium (Figure 3) did not correlate with delayed and less production of actinorhodin in R2YE medium (Figure 4).

Like in 4F, M145 produced more actinorhodin in $\mathrm{R} 2 \mathrm{YE}$ medium at $30^{\circ} \mathrm{C}$ than at $37^{\circ} \mathrm{C}$, suggesting that expression of the actinorhodin biosynthetic genes might be temperature-dependent. Temperature-dependent antibiotic gene clusters have been reported in Streptomyces, for example, much higher productivity of validamycin A produced by Streptomyces hygroscopicus was found at $37^{\circ} \mathrm{C}$ than at $30^{\circ} \mathrm{C}$ [40]. We infer that by replacement of thermophilic-specific promoters, many single genes and especially antibiotic genes clusters of mesophilic Streptomyces should be heterologously expressed in the fast-growing and thermophilic Streptomyces.

Table 3 Transformation by plasmids of the moderately thermophilic Streptomyces $2 \mathrm{C}$ and $\mathbf{4 F}$

\begin{tabular}{|c|c|c|c|c|}
\hline \multirow[t]{2}{*}{ Plasmids } & \multirow[t]{2}{*}{ Replicons } & \multirow[t]{2}{*}{ Hosts } & \multicolumn{2}{|c|}{ 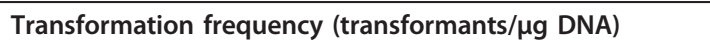 } \\
\hline & & & $2 \mathrm{C}$ & $4 \mathrm{~F}$ \\
\hline plJ702 & plJ101 & S. lividans ZX7 & $1.3 \times 10^{6}$ & $3 \times 10^{2}$ \\
\hline plJ702 & plJ101 & $2 \mathrm{C}$ & $2.9 \times 10^{6}$ & $8 \times 10^{1}$ \\
\hline plJ702 & plJ101 & $4 \mathrm{~F}$ & $1.4 \times 10^{5}$ & $1.2 \times 10^{5}$ \\
\hline $\mathrm{pCWH1}$ & pTSC1 & E. coli DH5 $\alpha$ & $1.3 \times 10^{3}$ & $2 \times 10^{1}$ \\
\hline pZR51 & pFRL2 & E. coli DH5 $\alpha$ & $8.2 \times 10^{3}$ & $1 \times 10^{1}$ \\
\hline pZR115 & pFP1 & E. coli DH5 $\alpha$ & $1 \times 10^{2}$ & $2 \times 10^{1}$ \\
\hline pZR10 & pFP11 & E. coli DH5 $\alpha$ & $2 \times 10^{2}$ & 1 \\
\hline
\end{tabular}




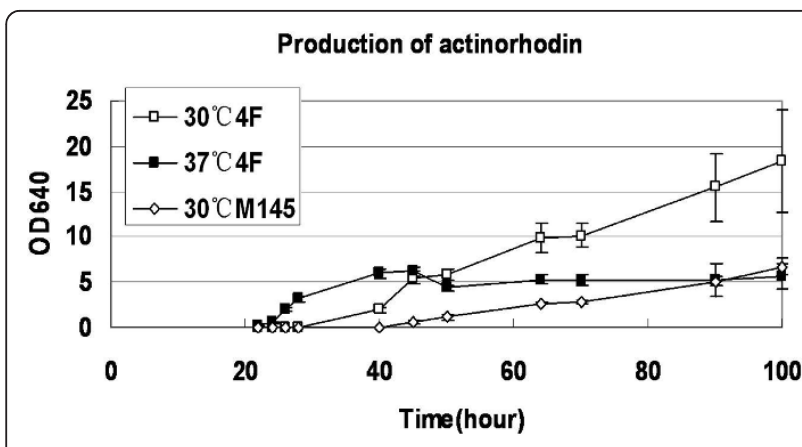

Figure 4 Quantitation of actinorhodin production by M145 and by $4 \mathrm{~F}$ containing the cloned actinorhodin gene cluster in liquid medium. About $1 \times 10^{6}$ spores of M145 and of $4 \mathrm{~F}$ containing pCWH74 were inoculated into $50 \mathrm{ml}$ R2YE liquid medium (lacking $\mathrm{KH}_{2} \mathrm{PO}_{4}$ and $\left(\mathrm{CaCl}_{2}\right)$ at 30 and $37^{\circ} \mathrm{C}$. Samples of $1 \mathrm{ml}$ culture were harvested in a time-course and treated with $\mathrm{KOH}$; absorption at OD640 indicated actinorhodin production.

Heterologous expression of the anthramycin biosynthetic gene cluster of the thermophilic $S$. refuineus subsp.

thermotolerans in strain $4 \mathrm{~F}$

Expression of the anthramycin biosynthetic genes of S. refuineus subsp. thermotolerans could be detected at high temperature (i.e. $47^{\circ} \mathrm{C}$ ), but not at 30 or $37^{\circ} \mathrm{C}$ [22]. An integrating cosmid, 024COA-3, containing the whole anthramycin biosynthetic gene cluster was introduced by conjugation from E. coli into strain 4F. PCR amplification experiments confirmed the presence of the anthramycin genes in the clone of 4F. After culturing in AP1 medium at 30,37 and $47^{\circ} \mathrm{C}$ for $24 \mathrm{~h}$, mycelium was extracted, dried and re-dissolved in $\mathrm{MeOH}$. Thin-layer chromatography, followed by a bio-assay by overlaying with LB agar containing as indicator strain a Bacillus sp., revealed a zone of growth inhibition on $4 \mathrm{~F}$ at $47^{\circ} \mathrm{C}$, but no inhibition zone was found at 30 and $37^{\circ} \mathrm{C}$ (data not shown). A spot on a TLC plate was further purified for HPLC-MS analysis. As shown in Figure 5, an anthramycin-specific peak (ES+ $=316$ Dalton, see ref [41]) was detected. Thus the anthramycin biosynthetic gene cluster of the thermophilic S. refuineus subsp. thermotolerans was heterologously expressed in strain $4 \mathrm{~F}$. We introduced the same cosmid 024COA-3 containing the anthramycin gene cluster into strain $2 \mathrm{C}$, but no transformants were obtained. To see if strain $2 \mathrm{C}$ might be a better host than $4 \mathrm{~F}$, more antibiotic biosynthetic gene clusters should be tested.

\section{Conclusions}

This study shows that by isolation of new strains and testing several plasmids, a host-vector system in a fastgrowing and moderately thermophilic Streptomyces species could be developed. Two antibiotic biosynthetic gene clusters from mesophilic and thermophilic Streptomyces were heterlogously expressed in one strain. We expect

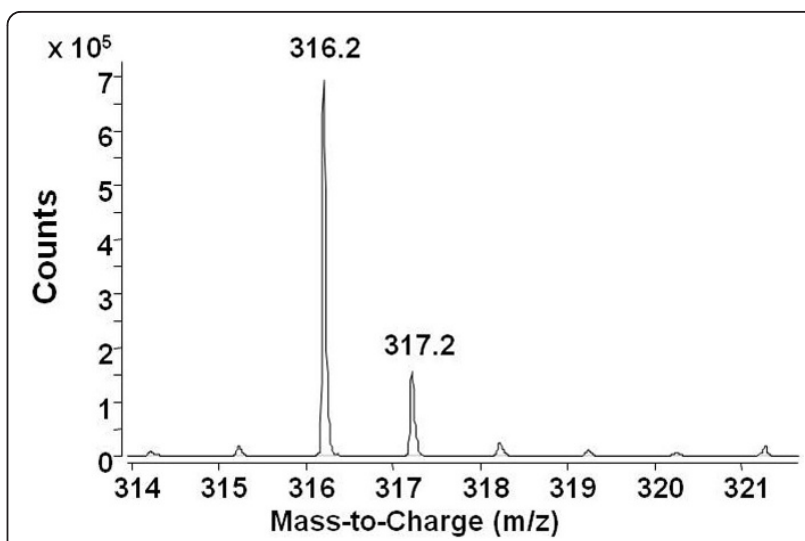

Figure 5 Analysis of anthramycin production by HPLC/MS. After separating anthramycin on an HPLC column, mass spectrometry was performed using 6520 Agilent Accurate-Mass Q-TOF LC/MS.

that by utilizing thermophilic Streptomyces-specific promoters, more genes and especially antibiotic genes clusters of mesophilic Streptomyces should be heterologously expressed.

\section{Methods}

Bacterial strains, plasmids, and general methods

Strains used in this work are listed in Table 1. Plasmid isolation, transformation of E. coli DH5 $\alpha$ and PCR amplification followed Sambrook et al. [42]. Streptomyces culture, plasmid isolation and preparation of protoplasts and transformation of Streptomyces lividans ZX7 followed Kieser et al. [6]. Plasmid trans-conjugation from E. coli ET12567/pUZ8002 into thermophilic Streptomyces strains followed Bierman et al. [38]. KpnI-treated pTSC1 was cloned in pBluescript II SK to obtain pCWH100 and was sequenced by primer-walking at Shanghai Invitrogen Inc. Sequence comparisons were done with software from the National Center for Biotechnology Information http://www.ncbi.nlm.nih.gov/BLAST. The complete nucleotide sequence of pTSC1 was deposited in the GenBank database under no. GU271942.

\section{Isolation and identification of thermophilic Streptomyces strains}

Samples of garden soil, weed compost and swine manure were collected from Shanghai city, Hunan, Hubei and Fujian provinces in the summers of 2005 and 2006. The samples were dried at $100^{\circ} \mathrm{C}$ for $1 \mathrm{~h}$ and cultivated on $\mathrm{SC}$ medium (starch $10 \mathrm{~g}$, casein $0.3 \mathrm{~g}, \mathrm{KNO}_{3} 2 \mathrm{~g}$, $\mathrm{MgSO}_{4} .7 \mathrm{H}_{2} \mathrm{O} 0.05 \mathrm{~g}, \mathrm{FeSO}_{4} .7 \mathrm{H}_{2} \mathrm{O} 0.01 \mathrm{~g}, \mathrm{CaCO}_{3} 0.02 \mathrm{~g}$, agar $18 \mathrm{~g}, \mathrm{H}_{2} \mathrm{O}$ to $1000 \mathrm{ml}, \mathrm{pH} 7.2$ ) [43] at $50^{\circ} \mathrm{C}$ for 3-5 d. Thermophilic Streptomyces strains were cultured in TSB (Oxoid tryptone soya broth powder, $30 \mathrm{~g}, \mathrm{H}_{2} \mathrm{O}$ to 1000 $\mathrm{ml}$ ) liquid medium at $45^{\circ} \mathrm{C}$ for $1 \mathrm{~d}$ and genomic DNA was isolated followed the Kirby mix procedure [6]. 16S rRNA 
genes were amplified by PCR with primers (5'-AGAG TTTGATCCTGGCTCAG-3' and 5'-TCAGGCTACCTT GTTACGACTT-3'). PCR conditions were: template DNA denatured at $95^{\circ} \mathrm{C}$ for $5 \mathrm{~min}$, then $95^{\circ} \mathrm{C} 30 \mathrm{~s}, 55^{\circ} \mathrm{C} 30 \mathrm{~s}$, $72^{\circ} \mathrm{C} 2 \mathrm{~min}$, for 35 cycles. PCR products were cloned in pBluescript II SK and sequenced with its T7 and T3 primers.

Strains were inoculated on MS (mannitol 20 g, soya flour $20 \mathrm{~g}$, agar $20 \mathrm{~g}, \mathrm{H}_{2} \mathrm{O}$ to $1000 \mathrm{ml}, \mathrm{pH} 7$ ) medium covered with cellophane disks. After 2 days incubation at $42^{\circ} \mathrm{C}$, the cells were fixed with fresh $2 \%$ glutaraldehyde (pH7.2) and 1\% osmium tetroxide. Spores were examined with a JSM-6360LV scanning electron microscopy (Jeol).

\section{Isolation of plasmids from thermophilic Streptomyces strains}

Isolating plasmid from thermophilic Streptomyces strains followed the protocol of Kieser [44] with sight modification. Strains were cultured in TSB liquid medium at $42^{\circ} \mathrm{C}$ overnight and mycelium was harvested by spinning at $4000 \mathrm{rpm}$ for $15 \mathrm{~min}$. About $50 \mu \mathrm{l}$ mycelium was suspended in $350 \mu \mathrm{l}$ TES buffer $(25 \mathrm{mM}$ Tris-HCL pH8, $25 \mathrm{mM}$ EDTA pH8, $0.3 \mathrm{M}$ sucrose, $2 \mathrm{mg} / \mathrm{ml}$ lysozyme, $5 \mu \mathrm{g} / \mathrm{ml}$ pre-boiled RNase A) and incubated at $37^{\circ} \mathrm{C}$ for $30 \mathrm{~min} .44 \mathrm{\mu l}$ of $10 \%$ SDS was added and mixed immediately by rotating and then $4 \mu \mathrm{l}$ of $10 \mathrm{mg} / \mathrm{ml}$ proteinase $\mathrm{K}$ was added, followed by incubation for $60 \mathrm{~min}$. $225 \mu \mathrm{l}$ of $0.3 \mathrm{~N} \mathrm{NaOH} / 2 \%$ SDS was added and mixed immediately by vortexing, incubated at $70^{\circ} \mathrm{C}$ for $15 \mathrm{~min}$ and then cooled. $200 \mu \mathrm{l}$ acid phenol/chloroform was added and vortexed and centrifuged at $12000 \mathrm{rpm}$ for $10 \mathrm{~min}$. The supernatant was transferred to a new centrifuge tube containing $55 \mu \mathrm{l}$ un-buffered sodium acetate and $500 \mu \mathrm{l}$ isopropanol was added. After mixing and centrifugation at $12000 \mathrm{rpm}$ for $10 \mathrm{~min}$ and all liquid was removed using a pipette. The pellet was washed twice with $1 \mathrm{ml} \mathrm{70 \%} \mathrm{etha-}$ nol, air dried and dissolved in $50 \mu \mathrm{l}$ TE buffer.

\section{Growth curve of thermophilic Streptomyces strains in liquid culture}

About $1.5 \times 10^{7}$ spores were inoculated into $50 \mathrm{ml}$ TSB liquid medium supplemented with $0.01 \%$ antifoam 289 (Sigma A 5551) and cultured at 30, 37, 45 and $50^{\circ} \mathrm{C} .1 \mathrm{ml}$ culture was harvested at each time-point and wet mycelium was harvested by centrifugation at $12000 \mathrm{rpm}$ for $5 \mathrm{~min}$. After drying for $10 \mathrm{~min}$ in a vacuum, the pellet was weighed with a fine balance (min. $10 \mathrm{mg}$ ). Growth curves were drawn with an average of three weighings at each time-point.

\section{Protoplast preparation and transformation of thermophilic Streptomyces strains}

Protoplast preparation, regeneration and transformation of the thermophilic Streptomyces strains $2 \mathrm{C}$ and $4 \mathrm{~F}$ followed standard Streptomyces protocols [6,45] with slight modifications. About $1 \times 10^{9}$ spores were inoculated into 50-ml YEME liquid medium (yeast extract powder $3 \mathrm{~g}$, peptone $5 \mathrm{~g}$, malt extract powder $3 \mathrm{~g}$, glucose $10 \mathrm{~g}$, with $25 \%$ sucrose, $\mathrm{H}_{2} \mathrm{O}$ to $1000 \mathrm{ml}$, pH7, supplemented with $0.5 \%$ glycine for $2 \mathrm{C}$ and $0.3 \%$ for $4 \mathrm{~F}$ ) at $45^{\circ} \mathrm{C}$ for $\sim 7 \mathrm{~h}$. Mycelium was harvested, washed once with $10.3 \%$ sucrose, and $1 \mathrm{mg} / \mathrm{ml}$ lysozyme solution in $\mathrm{P}$ buffer was added at $30^{\circ} \mathrm{C}$ (ca. $15 \mathrm{~min}$ for $2 \mathrm{C}$ and $30 \mathrm{~min}$ for $4 \mathrm{~F}$ ) to make protoplasts. After transformation, regeneration of protoplasts was achieved on R2YE medium at $45^{\circ} \mathrm{C}$ for ca. $9 \mathrm{~h}$, to be selected by antibiotics.

\section{Construction of plasmids for transformation of thermophilic Streptomyces strains}

Plasmids used in this work are listed in Table 2. Sizes of circular plasmids pTSC1, pTSC2 and pTSC3 and linear plasmid pTSL1 from thermophilic Streptomyces strains were measured by electrophoresis with known DNA markers (i.e. 1-kb supercoiled ladder and sequenced circular/ linear plasmids). pQC156 [46] containing Streptomyces selection markers melC/tsr was cloned in an E.coli plasmid pSP72. KpnI-treated pTSC1 was cloned in pQC156 to obtain pCWH1. The mesophilic Streptomyces replicons, including circular plasmids SCP2 [34], pFP1 and pFP11 [33], linear plasmids SAP1 [36], pFRL2 [32] and pSHK1 [32], and integrating plasmid SLP1 [35], were cloned in pQC156 to yield pYQ40, pZR115, pZR10, pQC578, pHAQ61, pZR51, pGP9 and pZR205, respectively. These plasmids were introduced by protoplast transformation into thermophilic Streptomyces strains.

\section{Cloning and heterologous expression of the actinorhodin gene cluster in thermophilic Streptomyces}

pHAQ31 [47] contained an E.coli replication origin and two cos sites of Supercos1 [48] and Streptomyces selection markers melC/tsr genes [31]. pHAQ31-derived cosmid N7-85 contained the whole actinorhodin biosynthetic gene cluster (5510413-5543521 bp) from $S$. coelicolor A3 (2). A 3.4-kb XbaI/NheI fragment containing the phage фC31 integrase gene of pSET152 was cloned in a XbaI site of N7-85. The resulting plasmid, pCWH74, was introduced by conjugation from $E$. coli into thermophilic Streptomyces strains [38], which were cultured on R2YE (sucrose $103 \mathrm{~g}, \mathrm{~K}_{2} \mathrm{SO}_{4} 0.25 \mathrm{~g}, \mathrm{MgCl}_{2} \cdot 6 \mathrm{H}_{2} \mathrm{O} 10.12 \mathrm{~g}$, glucose $10 \mathrm{~g}$, Difco Casaminoacids $0.1 \mathrm{~g}$, trace element solution $2 \mathrm{ml}$, Difco yeast extract $5 \mathrm{~g}$, TES $5.73 \mathrm{~g}$, agar $22 \mathrm{~g}$, $\mathrm{H}_{2} \mathrm{O}$ to $1000 \mathrm{ml}$, after autoclave and add $0.5 \% \mathrm{KH}_{2} \mathrm{PO}_{4} 5$ $\mathrm{ml}, 5 \mathrm{M} \mathrm{CaCl}_{2} \cdot 2 \mathrm{H}_{2} \mathrm{O} 4 \mathrm{ml}, 20 \% \mathrm{~L}$-proline $15 \mathrm{ml}, 1 \mathrm{~N}$ $\mathrm{NaOH} 7 \mathrm{ml}$ ) and MS media at 30,37 and $45^{\circ} \mathrm{C}$ to detect blue actinorhodin pigment. To quantitate the production of actinorhodin, about $1 \times 10^{6}$ spores of M145 and 4F containing pCWH74 were inoculated into $50 \mathrm{ml}$ R2YE liquid medium (lacking $\mathrm{KH}_{2} \mathrm{PO}_{4}$ and $\mathrm{CaCl}_{2}$ ) at 30 and 
$37^{\circ} \mathrm{C} ; 1 \mathrm{ml}$ culture was harvested in a time-course and treated with $\mathrm{KOH}$, whereupon absorption at OD640 indicated actinorhodin production [39].

\section{Heterologous expression of the anthramycin biosynthetic gene cluster in thermophilic Streptomyces}

An integrating cosmid, 024COA-3, containing the whole anthramycin biosynthetic gene cluster (EU195114.1, 133150 bp) (kindly provided by Prof. Brian Bachmann) was introduced by conjugation from E. coli into strain 4F [38]. Detection of anthramycin production followed Hu et al. [41]. After culturing in AP1 (corn starch $10 \mathrm{~g}, 2 \%$ peptonized milk, yeast extract powder $30 \mathrm{~g}, \mathrm{H}_{2} \mathrm{O}$ to $1000 \mathrm{ml}$, pH7) medium at $47^{\circ} \mathrm{C}$ for $24 \mathrm{~h}$, mycelium was extracted, dried and re-dissolved in $\mathrm{MeOH}$. Anthramycin was first isolated on a HPLC column (Zorbax eclips $1.8 \mu \mathrm{m}$ XDBC18) and then mass spectrometry was performed using 6520 Agilent Accurate-Mass Q-TOF LC/MS. Anthramycin was separated by using a Zorbax eclips $1.8 \mu \mathrm{m}$ XDB$\mathrm{C} 18$ with a linear water-acetonitrile gradient containing $10 \mathrm{mM}$ ammonium acetate $(0.2 \mathrm{ml} / \mathrm{min})$. The electrospray needle of the mass spectrometer was at $4000 \mathrm{~V}$, the voltage of the skimmer was set to $65 \mathrm{~V}$, Oct RF Vpp750V, collision ev $45 \mathrm{~V}$, nebulizer pressure at $45 \mathrm{psig}$, and drying gas $\mathrm{N} 2350^{\circ} \mathrm{C} 9 \mathrm{~L} / \mathrm{min}$.

\section{Additional material}

Additional file 1: Predicted ORFs of plasmid pTSC1. Detailed

information and possible functions of the eight ORFs of PTSC1.

\section{Acknowledgements}

We are very grateful to Sir David Hopwood for critical reading of and useful suggestions and corrections on the manuscript. We thank Brian Bachmann for kindly providing a cosmid containing the anthramycin biosynthetic gene cluster, Keqian Yang for S. venezuelae ISP5230, and Yiguang Wang for S. glaucescens GLA 4-26. These investigations were supported by grants from the National Nature Science Foundation of China (30770045, 31121001), National "973" project (2011CBA00801, 2012CB721104) and the Chinese Academy of Sciences project (KSCX2-EW-G-13) to Z. Qin.

\section{Authors' contributions}

WHC designed and performed all the experiments. ZJQ was involved in project design, and prepared the manuscript. All authors read and approved the final manuscript. The authors declare no conflict of interest.

Received: 13 April 2011 Accepted: 28 October 2011

Published: 28 October 2011

\section{References}

1. Bérdy J: Bioactive microbial metabolites. J Antibiot (Tokyo) 2005, 58:1-26.

2. Chater KF: Genetics of differentiation in Streptomyces. Annu Rev Microbiol 1993, 47:685-713.

3. Hopwood DA: Forty years of genetics with Streptomyces: from in vivo through in vitro to in silico. Microbiology 1999, 145(Pt 9):2183-2202

4. Hopwood DA: Soil to genomics: the Streptomyces chromosome. Annu Rev Genet 2006, 40:1-23.
5. Hopwood DA, Kieser T, Wright HM, Bibb MJ: Plasmids, recombination and chromosome mapping in Streptomyces lividans 66. J Gen Microbiol 1983, 129:2257-2269.

6. Kieser T, Bibb MJ, Buttner MJ, Chater KF, Hopwood DA: Practical Streptomyces Genetics. The John Innes Institute, The John Innes Foundation Press; 2000.

7. Gilbert R: Ueber Actinomyces thermophilus und andere Actinomyceten. Zeitschrift für Hygiene und Infektionskeiten 1904, 47:383-406.

8. Waksman SA, Umbreit WW, Cordon TC: Thermophilic actinomycetes and fungi in soils and in composts. Soil Science 1939, 47:37-61.

9. Skerman VBD, McGowan V, Sneath PHA: Approved lists of bacterial names. Int J Syst Bacteriol 1980, 30:225-420.

10. Goodfellow M, Lacey J, Todd C: Numerical classification of thermophilic streptomycetes. J Gen Microbiol 1987, 133:3135-3149.

11. Kim SB, Falconer C, Williams E, Goodfellow M: Streptomyces thermocarboxydovorans sp. nov. and Streptomyces thermocarboxydus sp. nov., two moderately thermophilic carboxydotrophic species from soil. Int J Syst Bacteriol 1998, 48:59-68.

12. Kim SB, Goodfellow M: Streptomyces thermospinisporus sp. nov., a moderately thermophilic carboxydotrophic streptomycete isolated from soil. Int J Syst Evol Microbiol 2002, 52:1225-1228.

13. $X u L H$, Tiang $Y Q$, Zhang YF, Zhao LX, Jiang CL: Streptomyces thermogriseus, a new species of the genus Streptomyces from soil, lake and hot-spring. Int J Syst Bacteriol 1998, 48:1089-1093.

14. Gadkari D, Schricker K, Acker G, Kroppenstedt RM, Meyer O: Streptomyces thermoautotrophicus sp. nov., a thermophilic $\mathrm{CO}$ - and $\mathrm{H}(2)$-oxidizing obligate chemolithoautotroph. Appl Environ Microbiol 1990, 56:3727-3734.

15. Edwards C: Isolation properties and potential applications of thermophilic actinomycetes. App/ Biochem Biotech 1993, 42:161-179.

16. James PD, Edwards $C$ : The effects of temperature on growth and production of the antibiotic granaticin by a thermotolerant streptomycete. J Gen Microbiol 1989, 135:1997-2003.

17. Tsujibo H, Miyamoto K, Kuda T, Minami K, Sakamoto T, Hasegawa T, Inamori Y: Purification, properties, and partial amino acid sequences of thermostable xylanases from Streptomyces thermoviolaceus OPC-520. Appl Environ Microbiol 1992, 58:371-375.

18. Bahri SM, Ward JM: Sequence of the Streptomyces thermoviolaceus CUB74 alpha-amylase-encoding gene and its transcription analysis in Streptomyces lividans. Gene 1993, 127:133-137.

19. Leimgruber W, Stefanović V, Schenker F, Karr A, Berger J: Isolation and characterization of anthramycin, a new antitumor antibiotic. J Am Chem Soc 1965, 87:5791-5793.

20. Mellouli L, Guerineau M, Bejar S, Virolle MJ: Regulation of the expression of amy TO1 encoding a thermostable alpha-amylase from Streptomyces sp. TO1, in its original host and in Streptomyces lividans TK24. FEMS Microbiol Lett 1999, 181:31-39.

21. Park HJ, Kim ES: An inducible Streptomyces gene cluster involved in aromatic compound metabolism. FEMS Microbiol Lett 2003, 226:151-157.

22. Hu Y, Phelan W, Farnet CM, Zazopoulos E, Bachmann BO: Reassembly of anthramycin biosynthetic gene cluster by using recombinogenic cassettes. Chembiochem 2008, 9:1603-1608.

23. O'Donnell AG, Falconer C, Goodfellow M, Ward AC, Williams E: Biosystematics and diversity amongst novel carboxydotrophic actinomycetes. Antonie Van Leeuwenhoek 1993, 64:325-340.

24. Saitou N, Nei M: The neighbor-joining method: a new method for reconstructing phylogenetic trees. Mol Biol Evol 1987, 4:406-425.

25. Kim D, Chun J, Sahin N, Hah Y, Goodfellow M: Analysis of thermophilic clades within the genus Streptomyces by $16 \mathrm{~S}$ ribosomal DNA sequence comparisons. Int J Syst Bacteriol 1996, 46:581-587.

26. Manteca A, Alvarez R, Salazar N, Yagüe P, Sanchez J: Mycelium differentiation and antibiotic production in submerged cultures of Streptomyces coelicolor. Appl Environ Microbiol 2008, 74:3877-3886.

27. Bentley SD, Chater KF, Cerdeno-Tarraga AM, Challis GL, Thomson NR, James KD, Harris DE, Quail MA, Kieser H, Harper D, Bateman A, Brown S, Chandra G, Chen CW, Collins M, Cronin A, Fraser A, Goble A, Hidalgo J, Hornsby T, Howarth S, Huang CH, Kieser T, Larke L, Murphy L, Oliver K, O'Neil S, Rabbinowitsch E, Rajandream MA, Rutherford K, Rutter S, Seeger K, Saunders S, Sharp D, Squares R, Squares S, Taylor K, Warren T, Wietzorrek A, Woodward J, Barrell BG, Parkhill J, Hopwood DA: Complete genome sequence of the model actinomycete Streptomyces coelicolor A3(2). Nature 2002, 417:141-147. 
28. Ishikawa J, Hotta K: FramePlot: a new implementation of the frame analysis for predicting protein-coding regions in bacterial DNA with a high G + C content. FEMS Microbiol Lett 1999, 174:251-253.

29. Kieser T, Hopwood DA, Wright HM, Thompson CJ: plJ101, a multi-copy broad host-range Streptomyces plasmid: functional analysis and development of DNA cloning vectors. Mol Gen Genet 1982, 185(2):223-238.

30. Mendes MV, Aparicio JF, Martin JF: Complete nucleotide sequence and characterization of pSNA1 from pimaricin-producing Streptomyces natalensis that replicates by a rolling circle mechanism. Plasmid 2000, 43(2):159-165.

31. Katz E, Thompson CJ, Hopwood DA: Cloning and expression of the tyrosinase gene from Streptomyces antibioticus in Streptomyces lividans. J Gen Microbiol 1983, 129:2703-2714.

32. Zhang R, Xia H, Guo P, Qin Z: Variation in the replication loci of Streptomyces linear plasmids. FEMS Microbiol Lett 2009, 290:209-216.

33. Zhang R, Zeng A, Fang P, Qin Z: Characterization of the replication and conjugation loci of Streptomyces circular plasmids pFP11 and pFP1 and their ability to propagate in linear mode with artificially attached telomeres. Appl Environ Microbiol 2008, 74:3368-3376.

34. Haug I, Weissenborn A, Brolle D, Bentley S, Kieser T, Altenbuchner J: Streptomyces coelicolor A3(2) plasmid SCP2*: deductions from the complete sequence. Microbiology 2003, 149:505-513.

35. Bibb MJ, Ward JM, Kieser T, Cohen SN, Hopwood DA: Excision of chromosomal DNA sequences from Streptomyces coelicolor forms a novel family of plasmids detectable in Streptomyces lividans. Mol Gen Genet 1981, 184(2):230-240.

36. Ikeda H, Ishikawa J, Hanamoto A, Shinose M, Kikuchi H, Shiba T, Sakaki Y, Hattori M, Omura S: Complete genome sequence and comparative analysis of the industrial microorganism Streptomyces avermitilis. Nat Biotechnol 2003, 21(5):526-531.

37. Zhou X, Deng Z, Firmin JL, Hopwood DA, Kieser T: Site-specific degradation of Streptomyces lividans DNA during electrophoresis in buffers contaminated with ferrous iron. Nucleic Acids Res 1988, 16:4341-4352.

38. Bierman M, Logan R, Obrien K, Seno ET, Rao RN, Schoner BE: Plasmid cloning vectors for the conjugal transfer of DNA from Escherichia coli to Streptomyces spp. Gene 1992, 116(1):43-49.

39. Bystrykh LV, FernandezMoreno MA, Herrema JK, Malpartida F, Hopwood DA, Dijkhuizen L: Production of actinorhodin related "blue pigments" by Streptomyces coelicolor A3(2). J Bacteriol 1996, 178(8):2238-2244.

40. Liao YQ, Wei ZH, Bai LQ, Deng ZX, Zhong JJ: Effect of fermentation temperature on validamycin A production by Streptomyces hygroscopicus 5008. J Biotechnol 2009, 142:271-274.

41. Hu Y, Phelan V, Ntai I, Farnet CM, Zazopoulos E, Bachmann BO: Benzodiazepine biosynthesis in Streptomyces refuineus. Chem Biol 2007, 14:691-701.

42. Sambrook J, Fritsch EF, Maniatis T: Molecular Cloning: A Laboratory Manual Cold Spring Harbor, Cold Spring Harbor Laboratory Press; 1989.

43. Mackay SJ: Improved enumeration of Streptomyces spp. on a starch casein salt medium. Appl Environ Microbiol 1977, 33:227-230.

44. Kieser T: Factors affecting the isolation of ccc DNA from Streptomyces lividans and Escherichia coli. Plasmid 1984, 12:19-36.

45. Bibb MJ, Ward JM, Hopwood DA: Transformation of plasmid DNA into Streptomyces at high frequency. Nature 1978, 274:398-400.

46. Qin Z, Shen M, Cohen SN: Identification and characterization of a pSLA2 plasmid locus required for linear DNA replication and circular plasmid stable inheritance in Streptomyces lividans. J Bacteriol 2003, 185:6575-6582.

47. Xia H, Huang J, Hu M, Shen M, Xie P, Zhang L, Wang H, Qin Z: Construction of an ordered cosmid library of $S$. avermitilis for genetic modification of the industrial strains. Chin J antibiot 2009, 34:340-343.

48. Evans GA, Lewis K, Rothenberg BE: High efficiency vectors for cosmid microcloning and genomic analysis. Gene 1989, 79(1):9-20.

49. Yang K, Han L, He J, Wang L, Vining LC: A repressor-response regulator gene pair controlling jadomycin B production in Streptomyces venezuelae ISP5230. Gene 2001, 279:165-173.

doi:10.1186/1471-2180-11-243

Cite this article as: Chen and Qin: Development of a gene cloning system in a fast-growing and moderately thermophilic Streptomyces species and heterologous expression of Streptomyces antibiotic biosynthetic gene clusters. BMC Microbiology 2011 11:243.

\section{Submit your next manuscript to BioMed Central and take full advantage of:}

- Convenient online submission

- Thorough peer review

- No space constraints or color figure charges

- Immediate publication on acceptance

- Inclusion in PubMed, CAS, Scopus and Google Scholar

- Research which is freely available for redistribution

Submit your manuscript at www.biomedcentral.com/submit
Biomed Central 